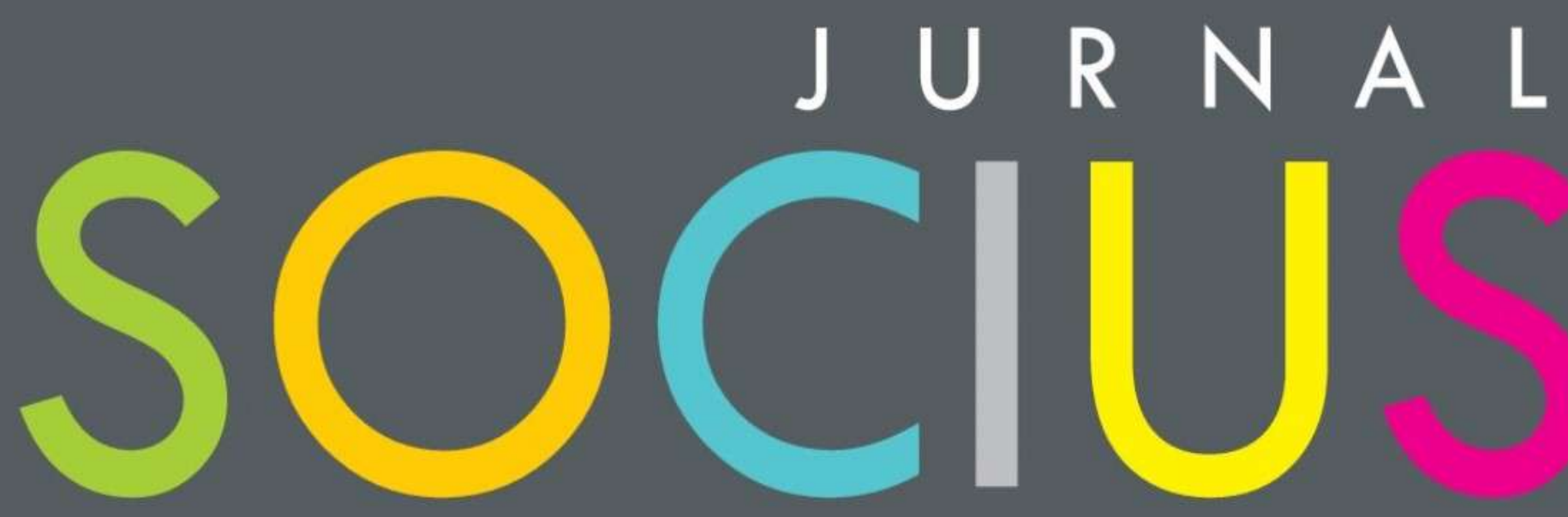

Journal of Sociology Research and Education

DITERBITKAN OLEH :

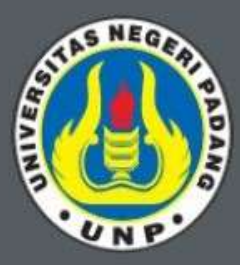

LABOR JURUSAN SOSIOLOGI FAKULTAS ILMU SOSIAL UNIVERSITAS NEGERI PADANG

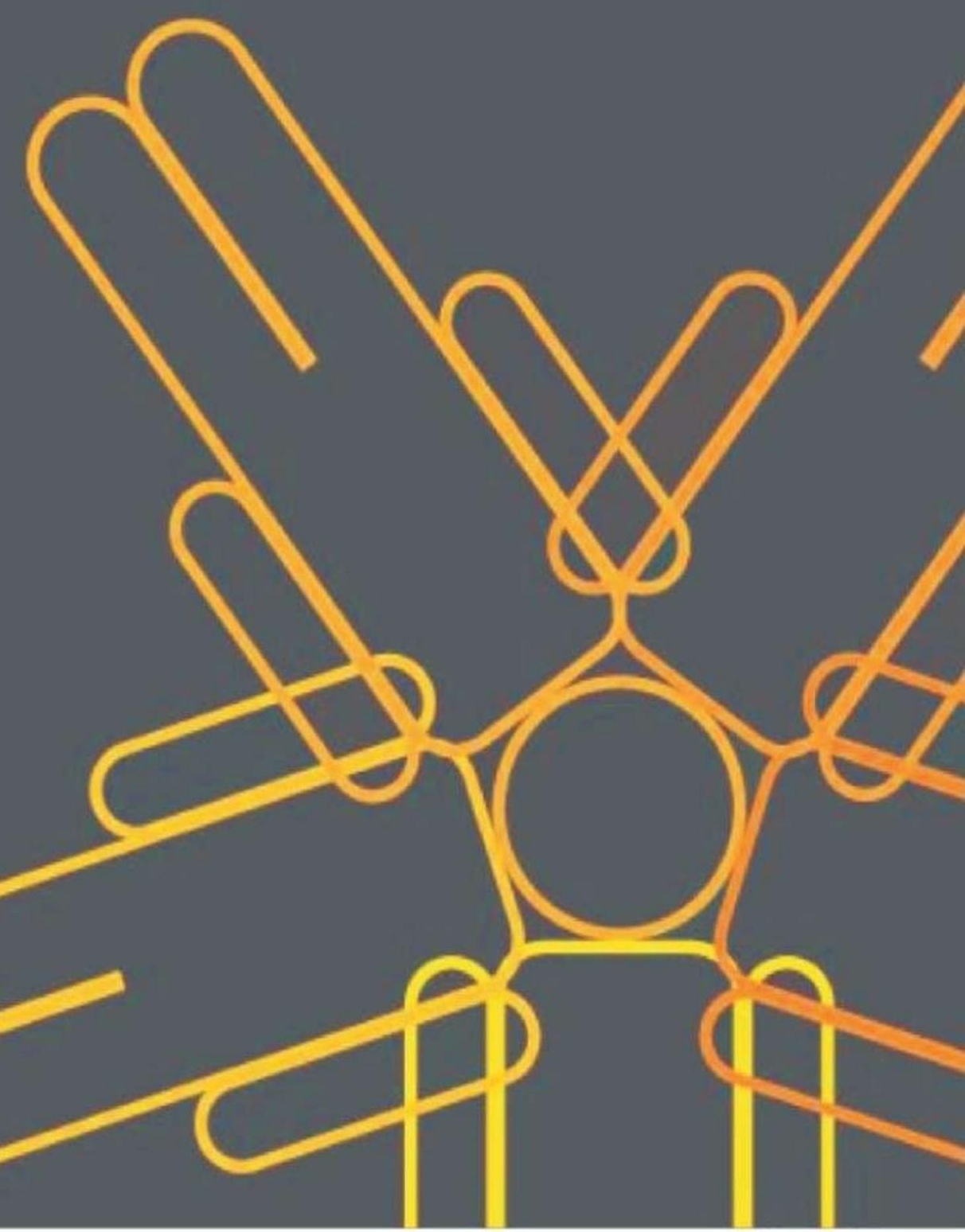




\section{SOCIUS}

Vol. 5, No.2, Th. 2018

ISSN : 2356-4180 (cetak)

2442-8663 (online)

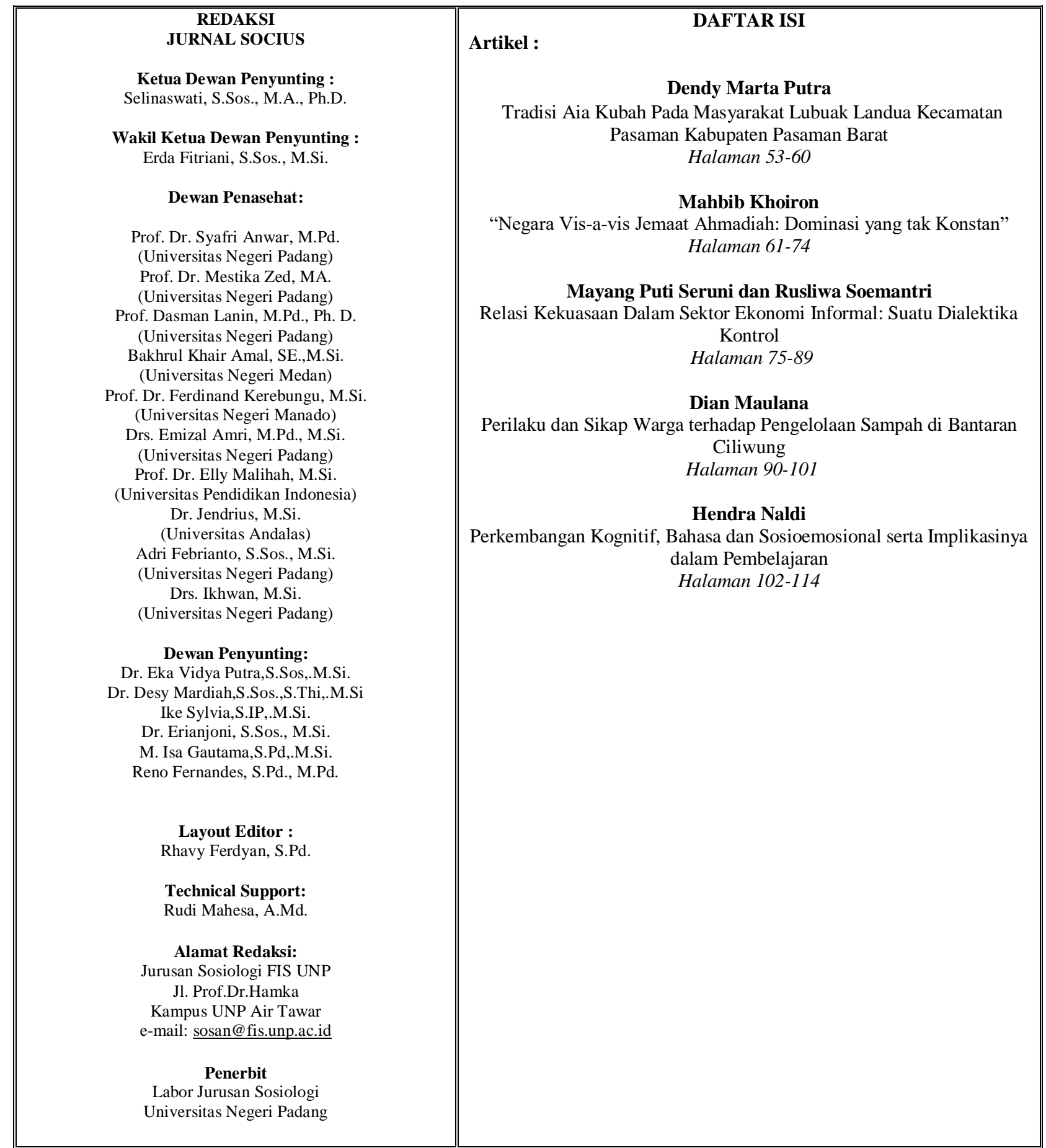




\title{
NEGARA VIS-À-VIS JEMAAT AHMADIYAH: DOMINASI YANG TAK KONSTAN
}

\author{
Mahbib Khoiron \\ Universitas Indonesia \\ Email: mahbib3008@gmail.com
}

\begin{abstract}
Abstrak
Penelitian ini mengamati praktik dominasi oleh institusi negara di tingkat lokal terhadap jemaat Ahmadiyah. Dominasi dilihat sebagai proses dengan memperhatikan kompleksitas relasi aktor-aktor yang terlibat di dalamnya. Melalui pendekatan kualitatif, terlihat bahwa negara dan masyarakat sejatinya bukan dua entitas yang diskret, dan yang satu selalu mendominasi yang lain. Kaburnya batas antara keduanya, ditambah perlawanan JAI yang khas, menjadikan praktik dominasi oleh negara tak selalu berjalan mulus. Inilah yang membuat JAI di berbagai tempat bisa menjalankan "normalitas" kehidupan-tidak melulu dalam kondisi terpuruk sebagaimana disimpulkan sebagian peneliti. Sebagian besar JAI tidak hanya eksis tapi juga tumbuh secara populasi.
\end{abstract}

Kata kunci: Negara, Ahmadiyah, Dominasi, State-in-society

\section{Abstract}

This study observed the effort of domination held by local level state institution towards Ahmadiyah community. Domination is seen as a process with paying attention to the relations complexity of the actors involved. Through a qualitative approach, it is revealed that the state and society are actually not two discrete entities, and one always dominates the other. The blurred boundaries between state and society, plus the typical JAI resistance, makes the state domination not always run smoothly. It is a reasons JAI community in various places able to carry out the "normality" of life - not only in the worst condition as some researchers concluded. Most JAI communities are not only can survive themselves but also develop their population.

Keywords: State, Ahmadiyah, Domination, State-in-society

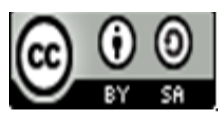

Received: October 30, 2018 Revised: December 3, $2018 \quad$ Available Online: December 21, 2018

\section{Pendahuluan}

Kasus Jemaat Ahmadiyah yang mencuat di media massa nyaris selalu mengundang perhatian publik. Setidaknya hal itu menyangkut dua isu utama: pertama, soal label "aliran sesat" yang disematkan kepadanya; kedua, persekusi terhadap jemaat Ahmadiyah sebagai kelompok minoritas di Indonesia. Kedua isu tersebut berikut kehebohan yang ditimbulkanya menarik para peneliti untuk banyak mencermati fenomena konflik yang terjadi, bukan hanya antara Ahmadi (sebutan untuk anggota jemaat Ahmadiyah) dan Muslim non-Ahmadi tetapi juga hubungan Ahmadi dan negara.

Pembahasan tentang negara tak bisa dilepaskan begitu saja karena berbagai tekanan yang dialami komunitas ini berkaitan erat dengan ragam kebijakan pemerintah. Lazimnya,

Jurnal Socius: Journal of Sociology Research and Education Vol. 5, No.2, Th. 2018 
analisa berangkat dari gejala berkembangnya aspirasi masyarakat Muslim kontra-Ahmadiyah kepada pemerintah untuk membubarkan Ahmadiyah di Indonesia, lalu negara atas pertimbangan sejumlah kepentingan politik tertentu mengakomodasi aspirasi itu dalam wujud regulasi atau kebijakan. Meski menggunakan pendekatan yang berbeda-beda, sebagaian besar peneliti belum keluar sudut pandang konflik dan memendam asumsi bahwa negara selalu berada dalam posisi dominan atas kelompok minoritas ini. ${ }^{1}$

Perdebatan tentang "yang benar" dan "yang sesat" lebih dari sekadar urusan teologi. Diskursus itu mencuat terkait dengan politik dominasi untuk memperebutkan siapa yang paling layak disebut sebagai "yang benar". Dalam konteks ini Ahmadiyah adalah korban dari politik dominasi itu dengan aktor utama negara dan otoritas agama seperti Majelis Ulama Indonesia (MUI). Nasib jemaat Ahmadiyah bahkan bisa dianalogikan seperti homo sacer, konsep hukum Romawi kuno yang dikembangkan Giogio Agamben untuk merujuk pada mereka yang boleh dibunuh namun tidak dikorbankan. Ahmadiyah yang dianggap telah melakukan "dosa besar" tidak diizinkan untuk dibunuh atau dianiaya, tetapi para pelakunya tak akan dituduh dengan dakwaan pembunuhan atau penganiayaan. ${ }^{2}$

Kesimpulan tak jauh beda diungkapkan pula oleh para pengaji dari Lembaga Ilmu Pengetahuan Indonesia (LIPI) ketika mengangkat isu ketahanan sosial pada minoritas pengungsi Syiah asal Sampang dan Jemaat Ahmadiyah Indonesia (JAI) asal Lombok Timur. Relasi negara dan JAI dilihat dari sejauh mana strategi pemerintah dalam mengatasi persoalan pengungsi dan relokasi. Riset yang diselenggarakan pada 2015 ini berkesimpulan bahwa negara berpihak pada gelombang penolakan terhadap eksistensi kaum Ahmadi, mempersulit proses legalitas identitas penduduk (KTP), dan sejumlah kebijakan yang mengekslusi lainnya. Fenomena ulama-politics sang gubernur dianggap memberi warna pilihan-pilihan kebijakan terhadap Ahmadiyah. ${ }^{3}$

Pandangan yang semacam ini secara umum sejalan-seiring dengan para pengamat lain yang menggunakan asumsi bahwa negara harus netral dalam menyikapi kelompok minoritas. Suara nyaring biasanya dilontarkan oleh para pengaji yang memaknai kasus Ahmadiyah di Indonesia dari perspektif pluralisme dan hak asasi manusia. ${ }^{4}$ Mereka menangkap bahwa negara berjalan terlalu jauh dengan masuk pada ruang tafsir agama yang seharusnya menjadi ruang privat warga negara. Penyimpangan peran negara terletak pada keberpihakannya pada tafsir arus utama sembari menyudutkan tafsir kelompok minoritas. Inilah indikasi adanya diskriminasi terhadap jemaat Ahmadiyah dan favoritisme atas umat Islam Sunni di negara

\footnotetext{
${ }^{1}$ Lihat, misalnya, Fatima Zainab Rahman. "State Restrictions on the Ahmadiyya Sect in Indonesia and Pakistan: Islam or Political Survival?. Australian Journal of Political Science 49:3(2014): 408-422; Muhammad As'ad. "Ahmadiyah and the Freedom of Religion in Indonesia." Journal of Indonesian Islam, Volume 03, Number 02, December 2009; Ahmad Najib Burhani. "Hating the Ahmadiyya: The Place of "Heretics" in Contemporary Indonesian Muslim Society." Contemporary Islam 8(2014):133-152.

${ }^{2}$ Ahmad Najib Burhani. 2013. When Muslims are not Muslims: The Ahmadiyya Community and the Discourse on Heresy in Indonesia (A dissertation submitted to the Faculty of the University of California). ProQuest LLC.

${ }^{3}$ Cahyo Pamungkas (ed). 2017. Mereka yang Terusir: Studi tentang Jetahanan Sosial Pengungsi Ahmadiyah dan Syiah di Indonesia. Jakarta: Yayasan Pustaka Obor Indonesia.

${ }^{4}$ Lihat: Zainal Abidin Bagir. 2017. Kerukunan dan Penodaan Agama: Alternatif Penanganan Masalah. Yogyakarta: Center for Religious and Cross-cultural Studies (CRCS); Human Rights Watch. 2013. Atas Nama Agama, Pelanggaran terhadap Minoritas Agama di Indonesia. tp.; Muhammad As'ad. "Ahmadiyah and the Freedom of Religion in Indonesia." Journal of Indonesian Islam, Volume 03, Number 02, December 2009; Ari Ganjar Herdiansah. "Public Policy and Religious Conflict in Indonesia: The Case of Ahmadiyah." Jurnal Wacana Politik, 1: 1(2016):53-61.
}

Jurnal Socius: Journal of Sociology Research and Education Vol. 5, No.2, Th. 2018 
non-agama, Indonesia. Pada titik inilah Ahmadiyah di Indonesia lekat dengan status sebagai kelompok minoritas yang tertindas, terzalimi, dikucilkan, bahkan lemah tak berdaya.

Ada kesamaan alasan dari para pengamat ketika melihat Ahmadiyah selalu dalam posisi subordinat di hadapan negara, yakni masih bercokolnya sejumlah peraturan diskriminatif yang memungkinkan terjadinya dominasi kelompok mayoritas dan negara terhadap minoritas. Terkait dengan Ahmadiyah, Surat Keputusan Bersama (SKB) yang ditandatangani Menteri Agama, Jaksa Agung, dan Menteri Dalam Negeri dinilai sebagai gambaran paling konkret dominasi negara yang terlembaga dalam regulasi. SKB tentang Ahmadiyah yang terbit pada 9 Juni 2008 itu berisi larangan untuk menyebarkan penafsiran dan kegiatannya yang menyimpang dari pokok-pokok ajaran Agama Islam. Pelanggaran terhadap ini berkonsekuensi hukum pada organisasi dan badan hukumnya.

Jika dicermati lebih dalam, sejumlah fakta empiris menunjukkan sesuatu yang paradoks dengan apa yang diasumsikan kebanyakan peneliti. Banyak peneliti cenderung mengambil kasus-kasus "memprihatinkan" yang dialami jemaat Ahmadiyah yang diperkirakan mencapai 400 ribu jiwa ${ }^{5}$ di Indonesia. Padahal, dari jumlah tersebut sebetulnya hanya sebagian kecil yang mengalami kondisi menyedihkan sebagaimana dicitrakan media massa: pembakaran atau penyegelan rumah ibadah, pengusiran, persekusi, dan aksi kekerasan lainnya. Selebihnya mereka tetap bertahan dan hidup "normal" tanpa mendapat gangguan berarti dari masyarakat dan negara.

Atau, kondisi jemaat Ahmadiyah juga lebih sering fluktuatif, tergantung pada turunnaiknya politik identitas yang dimainkan kelompok kontra-Ahmadiyah serta politik akomodasi yang dijalankan pemerintah. Berdasarkan hasil studi lapangan, Jemaat Ahmadiyah di Jakarta, misalnya, meski di beberapa tempat sempat mengalami tekanan, mayoritas mampu menjalankan aktivitasnya dengan baik. Bahkan, masing-masing mampu mengembangkan jumlah anggotanya. Beberapa kasus juga menunjukkan, upaya negara untuk menyegel masjid Ahmadiyah berujung gagal di tengah jalan.

Paradoks ini meniscayakan sudut pandang lain di luar relasi statis yang menampilkan negara sebagai yang selalu dominan. Perspektif alternatif ini penting untuk tidak terjebak pada hasil riset tentang relasi Ahmadiyah dan negara di atas yang masih menonjolkan dikotomisasi negara-masyarakat dengan corak hubungan yang asimetris. Dominasi negara atas jemaat Ahmadiyah dipandang seakan-akan berlangsung terus-menerus.

Pada poin ini, menarik untuk mengungkap sesuatu yang masih "bolong" dari belantara kajian soal relasi Ahmadiyah dan negara itu. Aspek tersebut antara lain meliputi studi-studi yang mengarah pada kaburnya batas hubungan antara negara dan masyarakat, serta runtuhnya klaim bahwa negara merupakan entitas yang selalu tampil dominan. Hal ini bisa dibaca misalnya lewat model relasi negara-masyarakat yang tak melulu bercorak statis atau konflik kelas. Dalam perkembangan kajian antropologi negara mutakhir, sudut pandang lain ini misalnya ditemui dalam pendekatan state in society. Secara praktis, ikhtiar ini bisa memberikan gambaran sisi lain relasi keduanya yang kerap menghebohkan jagat media, serta

\footnotetext{
The Association of Religious Data 2010. http://www.thearda.com/internationalData/countries/ Country_109_2.asp. Diakses 20 Oktober 2018. Namun berita ini segera dibantah Menteri Agama Suryadharma Ali dengan mengatakan bahwa jumlah kaum Ahmadi (sebutan untuk pengikut Ahmadiyah) di Tanah Air tak lebih dari 50 ribu orang saja (Republika.co.id, 10 Februari 2011). Yang jelas, komunitas yang telah berdiri di lebih dari 200 negara ini sukar diketahui jumlah pastinya. Sebab, banyak anggotanya yang enggan menunjukkan identitasnya. Amir Pengurus Besar JAI Abdul Basit menyebut jumlah jemaat Ahmadiyah di Indonesia terbesar di Asia (Suara.com, 13 Juni 2016).
}

Jurnal Socius: Journal of Sociology Research and Education Vol. 5, No.2, Th. 2018 
menjernihkan persoalan yang sedang atau kelak muncul ke permukaan yang berkenaan dengan relasi JAI dan negara.

\section{Metodologi Penelitian}

Penelitian ini menggunakan pendekatan kualitatif dan menerapkan aktivitas terpenting dalam studi etnografi, yakni turun lapangan (fieldwork). Selain wawancara mendalam dengan pihak-pihak yang relevan dengan fokus kajian, proses penelitian juga dilakukan dengan observasi partisipatif dalam sejumlah aktivitas jemaat Ahmadiyah Lenteng Agung. JAI Lenteng Agung dipilih karena pengalaman dan fenomena pada komunitas ini yang relevan dengan topik riset. Anggotanya yang mayoritas masyarakat urban, masjidnya pernah mengalami penyerbuan, hingga keberhasilan dalam mempertahankan dan mengembangkan dakwah. $^{6}$

Untuk kepentingan ini, peneliti menjalin kontak dan kedekatan langsung, baik dengan live in maupun mengikuti ragam kegiatan di sana baik menyangkut hubungan sosial dengan masyarakat sekitar, interaksinya dengan pemerintah, ritual yang dilakukan jemaat, forumforum internal organisasi, maupun lainnya.

Langkah ini dianggap efektif karena dengan demikian peneliti merasakan langsung sebagai "bagian internal" komunitas ini (immersion). Hal ini erat kaitannya terutama dengan usaha peneliti untuk mengungkap relasi negara-masyarakat sebagai daily practice (praktik sehari-hari) yang menjadi ciri khas studi antropologi negara kontemporer. Terlebih level negara yang hendak peneliti sorot ada di tingkat amat lokal, sehingga hanya mungkin diamati secara utuh dengan observasi terlibat. Melalui pergaulan dan pengamatan partisipatif di internal JAI dan masyarakat di sekitarnya, peneliti berharap bisa menangkap antara lain sejauhmana komunitas ini dekat dengan negara, pola-pola perlawanan terhadap dominasi, perjuangan mempertahankan kekhasan budaya, dan lain sebagainya.

Selama terlibat, peneliti berupaya memperkecil power yang memungkinkan data-data tertentu keluar secara tidak alami dari subjek penelitian. Karena itu, selain menerapkan participant observation ("mengamati secara terlibat"), peneliti juga menyadari pentingnya observation of participation ("mencermati keterlibatan"). Yang pertama mengharuskan seorang etnografer terjun lapangan sekaligus mengaktifkan sisi emosionalnya untuk memahami kebudayaan yang diteliti. Selain ikut serta dalam proses kebudayaan itu, ia diamdiam mengamati subjek penelitian sebagai pihak lain (others). Sementara yang kedua menuntut seorang etnografer untuk mencermati pengalaman keterlibatannya itu: apakah sudah menciptakan hubungan yang setara antara peneliti dan subjek yang diteliti atau belum. ${ }^{7}$ Peneliti meyakini bahwa keterlibatan (attachment) dan pengamatan (detachment) adalah hal yang niscaya dilakukan, meski bukan berarti mematok proses keduanya pada ikatan waktu tertentu karena hal itu berlangsung bolak-balik dan bisa terjadi kapan saja.

Studi pustaka dalam penelitian sudah barang tentu hal yang tak terelakkan. Kegiatan ini tidak hanya untuk menelaah teori tentang isu-isu yang relevan tapi juga mencari tahu sejauh mana penelitian-penelitian terdahulu sudah dibuat, baik dalam bentuk buku, tesis, disertasi, artikel di jurnal, dan lainnya. Studi pustaka ini tak menutup kemungkinan menjadi jalan

\footnotetext{
${ }^{6}$ Menurut pengakuan ketua cabang JAI Lenteng Agung, jumlah anggotanya kini sekitar 500 orang. Jumlah ini meningkat dari tahun-tahun sebelumnya. Sebab, penambahan orang baiat masuk Ahmadiyah selalu lebih besar dibanding orang keluar dari Ahmadiyah.

${ }^{7}$ Tedlock, Barbara. 1991. "From Participant Observation to The Observation of Participation: The Emergence of Narrative Ethnography", Journal of Anthropological Research 47(1):69-94.
} 
terkuaknya sejumlah data awal untuk bisa ditelusuri lebih lanjut oleh peneliti. Bukan saja kerangka konseptual, studi pustaka yang berkaitan langsung dengan JAI membantu peneliti dalam memperkaya ragam informasi tentang komunitas ini, termasuk kemungkinan membuat kesimpulan baru yang belum pernah diungkap oleh peneliti-peneliti sebelumnya.

\section{Jejak Kebijakan Negara terkait Ahmadiyah}

Sejak era kolonial Belanda, negara sudah mencitrakan dirinya sebagai pihak yang netral atas kelompok-kelompok agama. Namun, di saat bersamaan klaim itu diikuti kecurigaan dan kekhawatiran yang tinggi terhadap potensi politik Islam. Kebijakan keagamaan (Islam) di sini menjadi mendua. Di satu sisi, memberi kelonggaran yang besar kepada terhadap kebebasan beragama (Islam) dalam kaitannya dengan ibadah, tetapi di sisi lain terdapat restriksi terhadap kegiatan keagamaan yang (dicurigai) menjurus pada tindakan politik. Agak berbeda, pada zaman Jepang, kegiatan-kegiatan keagamaan (Islam) ditingkatkan kendati dalam kontrol dan pengawasan yang ketat. Peningkatan ini erat kaitannya dengan kepentingan Jepang yang mobilisasi masa untuk perang Asia-Rayanya. Kendati berbeda dalam orientasi dan kerangkanya, kebijakan Belanda dan Jepang ini sama-sama memberikan dampak yang mendalam bagi Indonesia merdeka dalam hal penataan, pengelolaan, dan pengaturan agama. ${ }^{8}$ Pasca-Indonesia merdeka, narasi itu tak sepenuhnya luntur. Sebagai presiden pertama Indonesia, Sukarno dalam banyak kesempatan menggelorakan narasi kesatuan bangsa Indonesia yang memang ia sadari memiliki kemajemukan luar biasa. Meski demikian, ia tak bisa menghindari munculnya perdebatan ideologis yang mewarnai proses penetapan dasar negara, antara kelompok yang pro "negara teokratis" (Islam) dan kelompok pendukung negara demokratis. Pancasila yang menjadi asas negara hingga sekarang adalah jalan tengah "paling maksimal" setelah pada Juli 1945 sempat muncul Piagam Jakarta yang memuat tujuh kata bias umat Islam pada sila pertama: "dengan kewajiban menjalankan syari'at Islam bagi pemeluk-pemeluknya".

Islam tidak serta merta secara total bisa dijinakkan. Orde Lama ternyata masih diwarnai pemberontakan-pemberontakan dari kubu islamis. Di antaranya datang dari kelompok gerilyawan Darul Islam di Aceh, Jawa Barat, Kalimantan Selatan, dan Sulawesi Selatan selama tahun 1950-an hingga awal 1960-an. Juga gerakan militer Permesta dalam kurun tahun 1956-1960, yang beberapa penggeraknya berasal dari partai Masyumi. Partai berisi aliansi beberapa kelompok Islam ini, yang sebelumnya aktif bersaing dalam pemilu, pun dibubarkan Sukarno pada tahun 1960 atas tuduhan terlibat dalam pemberontakan, di bawah rezim "Demokrasi Terpimpin". 9 Dari sini terlihat betapa Sukarno lebih banyak disibukkan dengan formasi negara yang ia pimpin. Kalaupun terkait Islam, hal itu spesifik yang berkenaan dengan kontestasi politik yang mengancam stabilitas kekuasaannya. Karena itu, sebagai gerakan kerohaniaan (bukan politik), Ahmadiyah bagi Orde Lama-sebagaimana juga pada zaman kolonial Belanda dan Jepang — nyaris tidak memiliki masalah. Bahkan, pada

\footnotetext{
${ }^{8}$ Anas Saidi, ed. 2004. Menekuk Agama, Membangun Tahta: Kebijakan Agama Orde Baru. Depok: Desantara, 2004. 33-52.

${ }^{9}$ John Olle. 2009. “The Majelis Ulama Indonesia versus 'Heresy': Th Resurgence of Authoritarian Islam”. State of Authority: The State ini Society in Indonesia. Ed. Klinken, Gerry van, and Joshua Barker. New York: Cornell Southeast Asia Program Publications.
}

Jurnal Socius: Journal of Sociology Research and Education Vol. 5, No.2, Th. 2018 
tahun 1953, pemerintah melalui Menteri Kehakiman RI menjadikan Ahmadiyah sebagai organisasi yang resmi berbadan hukum. ${ }^{10}$

Dibanding Sukarno, rezim otoriter Suharto dinilai lebih restriktif terhadap agama. Orde Baru dibangun dengan imaji kesatuan dan pembangunan nasional. Berbagai regulasi yang mengatur secara eksplisit kehidupan beragama lahir. Demi menjamin stabilitas, Orde Baru merasa perlu menerbitkan Surat Keputusan Bersama (SKB) Menteri Agama dan Menteri Dalam Negeri Nomor 1 Tahun 1969 tentang Pelaksanaan Tugas Aparatur Pemerintahan dalam Menjamin Ketertiban dan Kelancaran Pelaksanaan, Pengembangan dan Ibadat Agama oleh Pemeluk-pemeluknya. SKB ini lantas diderivasi menjadi regulasi dan program-program di tingkat kementerian dari masa ke masa.

Masalah penodaan agama secara resmi masuk dalam undang-undang juga terjadi di zaman Orba. UU Nomor 1/PNPS/1965 tentang Pencegahan Penyalahgunaan dan/atau Penodaan Agama semula adalah Penetapan Presiden (Penpres) Nomor 1 Tahun 1965 yang dikeluarkan Soekarno pada 27 Januari 1965. Setelah Soekarno jatuh, Majelis Permusyawaratan Rakyat Sementara (MPRS) memerintahkan untuk dilakukan peninjauan kembali produk-produk legislatif negara di luar produk MPRS yang tidak sesuai dengan Undang-Undang Dasar 1945. Berdasarkan hal tersebut dibentuk UU No.5 Tahun 1969 tentang Pernyataan Berbagai Penetapan Presiden dan Peraturan Presiden sebagai UndangUndang. ${ }^{11}$ Ditetapkanlah Penpres itu menjadi UU dan hingga kini kerap dijadikan "palu godam" oleh negara dan masyarakat untuk memarginalisasi sekte-sekte yang dinilai sesat atau menodai agama.

Di bawah kekuasaan Suharto, partai-partai Islam tidak begitu leluasa berkembang. Bahkan, pada 1973 Suharto membonsai partai-partai hanya menjadi tiga, dan partai-partai Islam menyatu di Partai Persatuan Pembangunan (PPP). Kebijakan berlanjut dengan memaksa seluruh ormas, termasuk organisasi Islam, untuk menjadikan Pancasila sebagai asas tunggal. ${ }^{12}$ Tapi di saat yang sama, di sela-sela kurun waktu itu, Orde Baru berinisiatif dan mensponsori berdirinya MUI pada tahun 1975. Porter menilai, secara umum MUI dihadirkan oleh Suharto sebagai corong kebijakan pemerintah. MUI berperan dalam melanggengkan kontrol sosial, menjelaskan ajaran Islam, dan menjamin harmoni di antara agama-agama. ${ }^{13}$

MUI pernah menerbitkan fatwa dalam Munas II Tahun 1980 bahwa Aliran Ahmadiyah berada di luar Islam, sesat dan menyesatkan. Namun, tampaknya proses restriksi terhadap Ahmadiyah tidak berjalan mulus sebagaimana pasca-reformasi, mengingat kuatnya kekuasaan Suharto. Bagi Orde Baru kondisi politik yang stabil adalah prioritas, sehingga elemen-elemen yang berusaha membuat kegaduhan-termasuk yang mengatasnamakan pemberantasan aliran sesat-akan dikendalikan olehnya. Itulah alasan yang mungkin mengapa MUI hanya membuat vonis sesat terhadap Ahmadiyah, tidak sampai pada rekomendasi pembubaran sebagaimana terbitan fatwa terbaru pada tahun 2005 tentang Aliran Ahmadiyah. Bahkan poin kedua dalam fatwa 1980 itu berbunyi "Dalam menghadapi persoalan Ahmadiyah hendaknya MUI selalu berhubungan dengan pemerintah." Fatwa ini

\footnotetext{
${ }^{10}$ Munasir Sidik. 2007. Dasar-dasar Hukum dan Legalitas Jemaat Ahmadiyah Indonesia. Tangerang: IKAHAI. 21

${ }^{11}$ Siti Aminah \& Uli Parulian S. 2011. Memahami Pendapat Berbeda (Dissenting Opinion) Putusan Uji Materiil UU Penodaan Agama. Jakarta: ILRC. 1-2.

${ }^{12}$ D.E. Ramage. 1995. Politics in Indonesia: Democracy, Islam, and the Ideology of Tolerance. London and New York: Routledge. 30.

${ }^{13}$ D.J. Porter. 2002. Managing Politics and Islam in Indonesia. London \& New York: Routledge Curzon. 76-83.
}

Jurnal Socius: Journal of Sociology Research and Education Vol. 5, No.2, Th. 2018 
mengindikasikan bahwa dalam menyikapi Ahmadiyah, MUI tidak berani bertindak di luar kontrol negara.

Fatwa MUI yang lebih tegas dan berani terbit pada tahun 2005 melalui Munas VII MUI. Di dalamnya terkandung pernyataan, "Pemerintah berkewajiban untuk melarang penyebaran paham Ahmadiyah di seluruh Indonesia dan membekukan organisasi serta menutup semua tempat kegiatannya." Sekitar dua minggu sebelum terbit telah terjadi penggerudukkan markas Pengurus Besar JAI di Parung, Bogor, oleh massa Front Pembela Islam (FPI) yang berusaha menggagalkan Jalsah Salanah, forum tahunan JAI berskala nasional. ${ }^{14}$ Ahmadiyah dianggap sebagai aliran yang meresahkan. Desakan kepada pemerintah untuk melarang Ahmadiyah terus digaungkan, beriringan dengan sejumlah persekusi terhadap kaum Ahmadi di beberapa tempat. Yang unik, justru dalih agar tidak terjadi anarkisme oleh masyarakat sipil, pemerintah merasa perlu didesak untuk menerbitkan aturan pelarangan Ahmadiyah. Era reformasi memang menjadi angin segar bagi kelompokkelompok militan Islam untuk mengekspresikan gerakannya. John Olle menamai situasi ini sebagai masa kebangkitan Islam otoritarian. ${ }^{15}$

Di antara wujud paling nyata dari gejala otoritarianisme Islam itu adalah terbitnya SKB Menteri Agama, Jaksa Agung, dan Menteri Dalam Negeri tentang Peringatan dan Perintah kepada Penganut, Anggota, dan/atau Anggota Pengurus Jemaat Ahmadiyah Indonesia (JAI) dan Warga Masyarakat. Butir dalam SKB yang ditandatangani pada 9 Juni 2008 di antaranya menyebutkan perintah untuk menghentikan penyebaran penafsiran dan kegiatan, serta ancaman sanksi terhadap organisasi dan badan hukum JAI bila tidak mengindahkan. Meskipun ini merupakan regulasi paling tersurat menggambarkan intervensi negara terhadap Ahmadiyah, tapi peraturan ini masih belum memuaskan FPI ${ }^{16}$ SKB ini-selain fatwa MUIpula yang menjadi salah satu pemicu tragedi Cikeusik yang menewaskan enam anggota JAI akibat bentrokan dengan warga. ${ }^{17}$

\section{Dominasi sebagai Proses}

Pendekatan untuk melihat relasi negara dan JAI masih didominasi oleh pendekatan statis dan konflik kelas. Keduanya (JAI dan negara) dianggap sebagai dua entitas terpisah dan stagnan dengan kedudukan yang tidak seimbang: negara kuat dan JAI lemah. Jikapun disebut "negara kalah" atau "negara lemah" umumnya merujuk pada ketakberdayaan negara menolak desakan ormas-ormas kekerasan kontra-Ahmadiyah, bukan lemah terhadap Ahmadiyah.

Dalam kesempatan ini penting menyuguhkan pendekatan proses dalam membaca kekuasaan negara guna memeriksa asumsi penulis tentang dominasi negara yang tidak konstan. Dalam perspektif ini, hubungan-hubungan formal tidak selalu lebih penting dari hubungan-hubungan informal. Dalam banyak kasus, justru relasi informallah yang sering menungkap kenyataan bahwa relasi negara-masyarakat sejatinya kompleks, fleksibel, dan melibatkan unsur-unsur yang belum tentu diskret antara satu dengan lainnya. Untuk keperluan ini, berikut penulis paparkan kasus fenomena di tingkat lokal yang merefleksikan

\footnotetext{
${ }^{14}$ Detik.com. Kampus Mubarak Jemaat Ahmadiyah Dijaga Ketat Polisi. 15 Juli 2005.

15 John Olle. 2009. "The Majelis Ulama Indonesia versus 'Heresy': Th Resurgence of Authoritarian Islam". State of Authority: The State ini Society in Indonesia. Ed. Klinken, Gerry van, and Joshua Barker. New York: Cornell Southeast Asia Program Publications.

${ }^{16}$ Detik.com. Habib Rizieq: SBY Pengecut, SKB Ahmadiyah Banci!. 10 Juni 2008.

${ }^{17}$ Kompas.com. Enam Jemaah Ahmadiyah Tewas. 6 Februari 2011.
} 
betapa proses dominasi tersebut tidak sederhana dan menyangkut relasi-relasi lain di luar hubungan formal negara vis-à-vis masyarakat.

\section{Papan Nama yang Gagal Dirobohkan}

Secara legal-formal, restriksi terhadap Ahmadiyah mendapat legitimasi hukumnya dari SKB Tiga Menteri yang terbit tahun 2008. Namun dalam praktiknya, eksekusi atas peraturan tersebut sangat tergantung pada kehendak pejabat di masing-masing daerah. Kehendak tersebut adakalanya inisiatif pribadi, tetapi lebih sering atas desakan sekelompok orang yang tidak menghendaki Ahmadiyah ada di lingkungannya. Momentum yang terakhir ini kita jumpai pada peringatan Milad FPI ke-10 yang diwarnai aksi turun jalan sembari meneriakkan tuntutan pembubaran Ahmadiyah. Lokasi utama aksi adalah di depan Istana Merdeka, lalu merembet ke lokasi-lokasi lain yang menjadi markas Ahmadiyah.

Suatu sore, sepulang dari longmarch ke Istana Merdeka, sekitar 100 anggota FPI menggeruduk Masjid al-Mubarak milik jemaat Ahmadiyah yang terletak di Jalan Kahfi II, Jagakarsa, Jakarta Selatan. Dengan menumpang mobil bak terbuka maupun sepeda motor, rombongan tiba di lokasi pada pukul 16.30 WIB. Ketegangan pun terjadi.

Koordinator aksi, Habib Novel dengan nada mengancam berujar, "Kami meminta sebelum bulan puasa, gedung tersebut tidak boleh menjadi masjid. Itu ditandai dengan penurunan papan nama. Jika tidak (diturunkan), kami akan bertindak sesuai cara kami." 18

Suasana sempat memanas tatkala massa FPI berusaha masuk ke dalam masjid yang pembangunannya baru selesai 80 persen itu. Massa FPI terlibat adu dorong dengan pagar betis polisi dan anggota Satpol PP di depan masjid. Beruntung kapolsek Jagakarsa dan camat setempat bisa menenangkan keadaan. Novel sepakat memberi toleransi sampai bulan puasa.

Setuju dengan negosiasi, massa lalu hanya berorasi di luar lingkungan masjid. Mereka juga sibuk menempelkan pamflet penolakan Ahmadiyah di papan nama dan pagar masjid tersebut. Sebelum membubarkan diri dengan berkonvoi, FPI sempat menempel pamflet di plang masjid itu yang bertuliskan, "Maklumat Al-Habib Muhammad Rizieq Shihab, SKB Ahmadiyah adalah SKB banci". ${ }^{19}$ Tidak tampak ada perlawanan dari massa Ahmadiyah. Lingkungan masjid terlihat sepi dan lengang.

Tak lama setelah kejadian itu, ketua RT setempat Pak Ms mendapat panggilan dari Kantor Kecamatan. Camat memberi instruksi kepada Pak Ms agar papan nama Masjid alMubarak segera dicopot. Sebagai bawahan, Pak Ms melaksanakan perintah tersebut. Tetapi, sebagai warga yang mendiami kelurahan Jagakarsa sejak 1980-an, Pak Ms tidak bisa melaksanakan instruksi tersebut secara frontal dan paksa. Meski secara keyakinan berbeda, Pak Ms sebelumnya tak memiliki masalah dengan jemaat di sana.

Secara umum warga sekitar Masjid al-Mubarak menoleransi kehadiran jemaat Ahmadiyah, termasuk jamaah Masjid al-Birru, masjid milik kelompok Sunni yang berada tepat 20 meter di seberang masjid Ahmadiyah. Pada 2008 sempat muncul narasi permusuhan terhadap JAI ketika para simpatisan Hizbut Tahrir Indonesia (HTI) sering menggelar halaqah (kajian) di Masjid al-Birru. Tapi itu tak berlangsung lama, karena pengurus ta'mir Masjid alBirru yang cenderung berpaham moderat tak menyukai permusuhan dengan kelompok lain. Ketua ta'mir Masjid al-Birru berganti secara turun-temurun tapi secara umum mereka punya kedekatan sosial dengan anggota JAI di sana.

\footnotetext{
${ }^{18}$ Detik.com, Masjid Ahmadiyah di Jagakarsa Diserbu Massa FPI, 27 Agustus 2008.

${ }^{19}$ Okezone, FPI Minta Masjid Ahmadiyah di Jagakarsa Ditutup, 27 Agustus 2008.
} 
Hubungan sosial keluarga Pak Ms dan jemaat Ahmadiyah juga tergolong baik. Anakanaknya yang memang lahir dan tumbuh di Jakarta tak jarang terlibat bermain dan nongkrong bersama dengan anak-anak jemaat di sana. Ketegangan Pak Ms dengan jemaat sedikit bergejolak ketika narasi tentang kesesatan Ahmadiyah santer di media massa, lalu otoritasnya sebagai ketua RT dituntut aktif dalam menyelesaikan kasus usaha penutupan masjid Ahmadiyah oleh massa FPI itu. Di sinilah letak kecanggungan Pak Ms menghadapi jemaat Ahmadiyah yang tak lain adalah tetangganya sendiri.

Saat mendatangi warga JAI, Pak Ms menyampaikan instruksi tersebut dengan bahasa informatif bahwa Camat Jagakarsa menghendaki papan nama Masjid al-Mubarak diturunkan. Jemaat menolak melakukan itu dan mempersilakan Pak Ms mencopotnya dengan tangan sendiri dan jemaat Ahmadiyah di sana akan merekam aksinya menurunkan papan nama Masjid. Untuk apa rekaman itu? Untuk dilaporkan kepada 'pihak pusat' bahwa ada ketua RT merobohkan papan nama Masjid yang didirikan secara sah.

Respons dari jemaat tersebut makin menyulitkan posisi Pak Ms. Di satu sisi ia ingin melaksanakan instruksi Camat. Tapi di sisi lain ia tak mau sekaligus jadi eksekutor lalu berurusan dengan pejabat di tingkat pusat. Pak Ms pun akhirnya menyudahi perkarannya dengan pulang tanpa menyentuh papan nama Masjid al-Mubarak sedikit pun. "Yang penting saya sudah menyampaikan apa yang menjadi kehendak Pemerintah Kecamatan," katanya.

Keributan ini pelan-pelan reda dengan sendirinya. Gagalnya Pak RT merobohkan papan nama masjid juga tidak mendapat tindak lanjut dari Camat. Seolah instruksi adalah sebatas instruksi, tidak ada tuntutan harus berhasil mengeksekusi. Begitu kegaduhan surut, serta ancaman FPI yang tidak terbukti, permasalahan seolah dianggap selesai. Masjid alMubarak-meski awal-awal sedikit terganggu aktivitasnya dan mendapat penjagaan ketat dari kepolisian-berangsur-angsur berfungsi normal. Shalat jamaah lima waktu tetap berlanjut, forum-forum pengjian terselenggara lancar, dan pengembangan jamaah juga relatif lancar.

Hingga sekarang hubungan Pak Ms dengan jemaat di sana tergolong akur. Seakan melupakan "tragedi papan nama masjid", jemaat di sana tidak segan-segan mengundang Pak Ms yang menjabat sebagai ketua RT selama beberapa periode sampai kini itu terlibat dalam kegiatan-kegiatan kemasyarakatan yang diadakan kaum Ahmadi Lenteng Agung. Keakraban tersebut tampak, misalnya, dengan hadirnya Pak Ms pada perayaan Hari Ulang Tahun Kemerdekaan RI yang digelar di sekitar Masjid al-Mubarak. Peringatan HUT RI biasanya diselenggarakan dengan ragam lomba untuk anak-anak, bakti sosial donor darah, atau lainnya. Atas nama pemimpin rukun tetangga, Pak Ms mendapat kesempatan untuk memberi pidato sambutan.

Tak sebatas memenuhi undangan, Pak Ms bahkan bersedia membantu pembagian daging kurban jemaat Ahmadiyah kepada warga tiap momen Idul Adha tiba. Daging kurban diberikan dalam jumlah banyak ke RT-nya untuk kemudian ia distribusikan ke rumah-rumah di kawasan RT setempat.

Yang menarik, di balik keramahan Pak Ms itu terselip juga keinginan agar jemaat Ahmadiyah dibubarkan, merujuk pada fatwa MUI dan SKB Tiga Menteri. Namun ia merasa tidak punya kekuasaan untuk itu. Baginya, daripada menimbulkan keributan yang tak perlu, Pak Ms lebih baik fokus pada tanggung jawabnya sekarang, yakni menjaga kedamaian dan kerukunan warga di lingkungannya. Toh, warga di RT-nya, seperti umumnya masyarakat Jakarta, cenderung permisif atas keyakinan orang lain selama tidak mengganggu. 
Alhasil, Masjid al-Mubarak sekarang bukan hanya papan namanya yang tetap utuh, tapi juga secara eksplisit berani menyebut nama "Ahmadiyah" di spanduk tambahan tiap hari-hari besar Islam seperti Idul Fitri dan Idul Adha, juga momen 17 Agustusan. Pada HUT Kemerdekaan RI yang ke-73, misalnya, JAI Lenteng Agung memasang spanduk tinggi-tinggi di dinding masjid yang menghadap ke jalan raya, dengan tulisan "Dirgahayu Republik Indonesia, Kerja Nyata Ahmadiyah untuk Negeri" diimbuhi logo resmi HUT Ke-73 RI sembari menyebut empat nama komunitas milik Ahmadiyah yang bergerak di bidang sosialkemanusiaan: Komunitas Give Blood, Komunitas Clean The City, Komunitas Donor Mata, dan Komunitas Humanity First Indonesia. Kasus yang mirip juga terjadi pada momen-momen penting lainnya.

\section{Analisis Data}

Kendatipun penelitian ini mengambil kasus lokal di Kelurahan Jagakarsa, proses dominasi di atas sesungguhnya merupakan pemandangan yang umum dijumpai pada jemaat Ahmadiah di lain-lain tempat, bahkan kelompok minoritas secara umum. Sesuai dengan pendekatan kualitatif yang dipakai, kasus ini merefleksikan fenomena yang lebih luas tentang kompleksitas relasi negara-masyarakat dan praktik dominasi yang tidak statis dan konstan.

Menurut Joel S. Migdal, kita harus menghindari perspektif yang hanya mempertentangkan negara dan masyarakat. Masyarakat dilihat bukan sebagai entitas monolitik tetapi sebagai "kumpulan organisasi sosial" seperti keluarga, klub, perusahaan, atau klan. Negara hanyalah satu organisasi di antara banyak komunitas ini. Asosiasi-asosiasi ini mengatur interaksi para anggotanya, serta antara anggota dan non-anggota ${ }^{20}$ Negara sejatinya diisi oleh aktor-aktor yang datang dari tak hanya dari institusi negara tapi juga kelompokkelompok masyarakat yang terikat oleh etnisitas, budaya, lokalitas, dan lainnya. Yang jarang dipahami adalah bahwa masyarakat dan negara kadang menjalin interaksi yang khas sehingga negara yang kerap diamati dalam kerangka "negara berdaulat atas masyarakat" bisa meleset. ${ }^{21}$. Dalam state in society negara adalah bagian dari masyarakat, dengan karakteristik yang tidak banyak berbeda dari organisasi sosial lainnya. Pejabat negara adalah anggota masyarakat yang lebih besar. Yang perlu dipilah adalah tiap pola khas interaksi dari mereka.

Dalam konteks ini, individu diasumsikan tetap memiliki otonominya. Imbalan dan sanksi yang disiapkan negara tak serta merta dipatuhi oleh anggotanya. Seperti disebutkan di atas, negara hanyalah satu dari organisasi sosial yang ada di masyarakat. Sementara, setiap orang umumnya adalah anggota dari banyak organisasi sosial, dan karenanya berhadapan dengan banyak sekali aturan (bukan semata aturan negara). Pilihan untuk patuh atau tidak patuh, ke arah organisasi mana ia lebih berpihak, sangat terkait dengan apa yang Migdal sebut sebagai strategi bertahan hidup (strategies of survival) demi memenuhi kebutuhan psikologis dan duniawinya. ${ }^{22}$

\footnotetext{
${ }^{20}$ Joel S. Migdal. 2004. State in Society: Studying How States and Societies Transform and Constitute One Another. New York: Cambridge University Press. 63.

${ }^{21}$ Lambach, Daniel. "State in Society: Joel Migdal and the Limits of State Authority." Political Concepts Beyond the Nation State: Cosmopolitanism, Territoriality, Democracy, Danish Political Theory Network Conference, University of Copenhagen, Department of Political Science Copenhagen, 27-30 October 2004.

${ }^{22}$ Joel S. Migdal. 2004. State in Society: Studying How States and Societies Transform and Constitute One Another. New York: Cambridge University Press. 252.
} 


\section{Kontenstasi Kuasa Negara-JAI}

Cerita tentang eksekusi perobohan papan nama masjid yang gagal tersebut lebih dari sekadar kegagalan Pak Ms melaksanakan instruksi Camat. Fenomena ini menggambarkan betapa praktik dominasi negara, yang memiliki legitimasi hukum dan struktur yang diandaikan koheren, tidak berjalan mudah.

Dalam konteks ini, legitimasi formal yang digunakan adalah SKB Tiga Menteri tentang Ahmadiyah. Lebih kuat lagi, sebagai tindak lanjut atas SKB ini, diterbitkan pula pada 6 Agustus 2008 Surat Edaran Bersama Sekjen Departemen Agama, Jaksa Agung Muda Intelijen, dan Dirjen Kesbangpol Departemen Dalam Negeri kepada Gubernur, Kepala Kejaksaan Tinggi, Kepala Kanwil Departemen Agama Provinsi, dan Bupati/Walikota di seluruh Indonesia. Isinya adalah perintah kepada mereka untuk melakukan sosialisasi, pembinaan, pengamanan, pengawasan, koordinasi dan pelaporan terkait Ahmadiyah. Asumsi pemerintah tentang adanya koherensi struktur pemerintahan makin terlihat dalam surat edaran ini. Sehingga, regulasi yang terbit dari pusat seharusnya bisa ditindak-lanjuti oleh strukturstruktur di bawahnya. ${ }^{23}$

Dengan demikian, di luar pengaruh tekanan massa FPI, apa yang diinstruksikan Camat kepada Pak Ms sebenarnya sudah memenuhi koherensi struktur politik formal di atasnya, yakni Walikota Jaksel dan Gubernur DKI Jakarta. Hanya saja, ketika instruksi dari pemerintah pusat itu turun ke bawah hingga level RT, keadaan menjadi lain akibat relasirelasi informal yang mempengaruhi keputusan aparat negara di tingkat paling bawah. Kecanggungan Pak Ms dalam meneruskan perintah Camat mencerminkan posisi Pak Ms yang tidak monolitik: murni sebagai pejabat negara. Selain sebagai ketua RT, Pak Ms juga mendudukkan dirinya sebagai tetangga yang baik dari jemaat Ahmadiyah. Pada titik inilah, batas antara negara dan masyarakat menjadi kabur (blurred). Negara ternyata hanyalah salah satu organisasi sosial yang diikuti, di samping organisasi sosial lain bernama "masyarakat Kelurahan Jagakarsa”.

Fenomena ini pula yang melingkupi mayoritas penganut non-Ahmadi di sekitar Masjid al-Mubarak. Secara teologis mereka membedakan diri dari Ahmadiyah tapi secara bersamaan mereka tidak sepakat dengan timbulnya disharmoni pada masyarakatnya. Di satu sisi mereka menegaskan identitasnya sendiri sebagai Muslim Ahlussunnah wal Jamaah, tetapi di sisi lain masih terikat dengan budaya dan lokalitas sebagai "masyarakat Kecamatan Jagakarsa". Itulah mengapa, tekanan langsung dari kalangan non-Ahmadi tidak pernah muncul dari masyarakat sekitar sendiri, melainkan massa FPI yang datang dari luar Jakarta Selatan.

Yang penting juga adalah penolakan JAI Lenteng Agung untuk mencopot papan nama Masjid al-Mubarak. Sikap ini merupakan penegasan akan otonomi kelompok yang menolak dikontrol penuh oleh negara dalam hal-hal yang merugikan eksistensi komunitasnya. Dalam kesehariannya, masing-masing anggota JAI termasuk warga negara yang patuh, masjidnya pun memiliki izin pendirian bangunan yang bisa dipertanggungjawabkan. Namun, karena penurunan plang masjid termasuk simbol penghentian aktivitas jemaat, kali ini mereka memberontak meski tidak dengan cara frontal.

\footnotetext{
${ }^{23}$ Dalam surat edaran sepanjang enam halaman tersebut termuat imbauan kepada pemerintah daerah untuk melakukan bimbingan yang meliputi pemberian nasihat, saran, petunjuk, pengarahan, atau penyuluhan keagamaan dan dakwah agar tidak melakukan perbuatan atau kegiatan seperti pidato, ceramah, khutbah, pengajian, pembaiatan, seminar, lokakarya, dan kegiatan lainnya, lisan maupun tulisan, dalam bentuk buku, dokumen organisasi, media cetak, dan media elektronik yang mengandung muatan dan dimaksudkan untuk penyebaran paham yang mengakui adanya nabi dan segala ajarannya setelah Nabi Muhammad SAW.
}

Jurnal Socius: Journal of Sociology Research and Education Vol. 5, No.2, Th. 2018 
Perilaku ini bisa dibaca sebagai fenomena individu-individu yang berada dalam situasi tarik-menarik di antara otoritas dua organisasi sosial, yakni negara dan jemaat Ahmadiyah yang tidak hanya berlingkup nasional tapi juga internasional. Pada kasus ini, orang-orang Ahmadi di sana lebih memilih kepatuhan kepada organisasi untuk melanggengkan syiar kebenaran daripada kepada negara ketika dalam praktiknya tidak berpihak pada hak-haknya. Pada tahap ini, kemampuan negara dalam mengontrol warga mendapat ujian, dan karenanya berpengaruh pada kegagalan upaya dominasinya.

Yang paling menarik adalah dalih yang digunakan jemaat Ahmadiyah dalam mempertahankan diri. Jika Pak Ms datang dengan membawa legitimasi dari Camat Jagakarsa saat menginstruksikan perobohan papan nama, jemaat Ahmadiyah pun menggunakan legitimasi lain dari negara untuk menolaknya. Ancaman akan "melaporkan ke pihak pusat" mengungkapkan adanya keyakinan dari JAI bahwa "negara" juga punya keberpihakan kepadanya. Selama observasi, penulis merasakan betul persepsi itu di kalangan Ahmadi. Ahmadiyah memandang regulasi yang melindungi eksistensinya jauh lebih besar dan kuat ketimbang regulasi yang menyatakan sebaliknya. Sejumlah peraturan yang mengekang kebebasan mereka dilihat sebagai inkonsistensi hukum di Indonesia yang pada dasarnya sangat menjunjung tinggi hak asasi manusia. ${ }^{24}$ Berangkat dari keyakinan ini pula, sejumlah komunitas Ahmadiyah merasa aman menggerakkan sejumlah program filantropi mereka, termasuk bila harus dilakukan secara terbuka.

Secara eksternal, resistensi JAI atas gangguan eksternal juga dibangun dengan menjalin aliansi taktis dengan kelompok-kelompok Muslim moderat, para pegiat kebebasan beragama, atau sejumlah pejabat negara yang toleran. JAI Lenteng Agung sebagai bagian dari JAI secara nasional (bahkan internasional) secara langsung maupun tidak langsung mendapat manfaat dari ikhtiar semacam ini. Aliansi taktis itu tampak dari pilihan tamu undangan pada forum-forum resmi JAI, atau kesediaan JAI hadir di simpul-simpul yang pro kebebasan dan kesetaraan. Upaya tersebut cukup menguatkan narasi tentang hak asasi mereka, meskipun narasi tentang "kesesatan" mereka sering lebih kuat lagi. Sejumlah pejabat di kawasan Jakarta Selatan mengaku tidak suka dengan keberadaan Ahmadiyah, tapi mereka tidak punya kuasa untuk melarangnya. Salah satu alasannya adalah kesadaran akan posisi pejabat negara yang mesti netral dan kekhawatiran tuduhan pelanggaran HAM yang ditimpakan kepada dirinya.

Dengan demikian, asumsi banyak peneliti yang mengesankan negara vis-à-vis JAI selalu merupakan relasi antara yang kuat dan yang lemah perlu diperiksa kembali. Pengamatan pada level mikro, dengan melihat kompleksitas hubungan para aktor yang terlibat, tampak bahwa proses dominasi oleh negara terhadap warganya tidak selalu berlangsung lancar. Konsepsi tentang yang kuat dan yang lemah pada akhirnya bersifat relatif dalam kenyataan empiris. Negara memang selalu ingin mencitrakan dirinya sebagai entitas paling kuat, tapi apakah citra itu selalu mewujud dalam praktiknya mesti diuji terlebih dahulu.

\section{Penutup}

Paparan di atas sampai pada satu kesimpulan bahwa hubungan antara negara dan Jemaat Ahmadiyah pada dasarnya sangat kompleks. Kerumitan hubungan itu dimulai sejak

${ }^{24}$ Penjelasan lebih lanjut soal basis hukum JAI bisa disimak dalam Munasir Sidik. 2007. Dasar-dasar Hukum dan Legalitas Jemaat Ahmadiyah Indonesia. Tangerang: IKAHAI.

Jurnal Socius: Journal of Sociology Research and Education Vol. 5, No.2, Th. 2018 
samarnya batas-batas antara negara dan masyarakat. Aparatus negara adalah aktor yang selain berasal dari institusi negara juga merangkap sebagai bagian dari kelompok sosial lain. Dari sinilah sering terjadi status yang ambigu dari seorang aparatus negara: tugasnya sebagai representasi negara tercampuri oleh posisinya sebagai bagian dari masyarakat. Kehendak negara untuk melakukan dominasi kerap terhambat di titik ini. Dalam penelitian ini, hambatan tersebut tercermin dari sikap canggung Pak RT, perubahan dari bahasa instruksi ke bahasa informasi, kemudian eksekusi pencopotan plang masjid yang gagal.

Sasaran dominasi, dalam hal ini JAI, juga tidak bisa dipandang sebagai individuindividu pasif. Mereka subjek otonom yang memiliki agensi untuk menentukan pilihan, melakukan siasat, atau melawan dengan cara mereka sendiri. Mereka mempunyai legitimasinya sendiri untuk mempertahankan diri atas nama negara, bahkan ketika negara itu sendiri yang jadi musuhnya. Konsepsi Indonesia sebagai negara hukum dan sederet peraturan yang mendukung terjaminnya kebebasan beragama/berkeyakinan adalah di antara instrumen yang membuat mereka selalu memiliki daya ketika mengalami kesulitan: menempuh jalur hukum, melapor ke "pihak pusat", dan lain sebagainya.

Dua aspek di atas, sangat erat kaitannya, dengan realitas kenapa jemaat Ahmadiyah di sejumlah tempat dalam situasi "normal" (lancar menjalankan aktivitas kejemaatan dan mengembangkan anggota). Mereka tidak selalu dalam kondisi terpuruk sebagaimana digambarkan beberapa ahli. Ditambah, relasi tidak semata negara-JAI tapi juga JAImasyarakat non-JAI. Ikatan sosial di antara mereka sangat berpengaruh pada kondusivitas JAI dalam melaksanakan kesehariannya. Masing-masing dari mereka mungkin saja membangun distingsi identitas, tapi bukan berarti mereka tidak bisa bertemu dalam identitas lainnya. Dalam hal ini, lokalitas, budaya, etnisitas, atau kesamaan kepentingan untuk hidup harmoni menjadi sarana penting bagi kohesivitas masyarakat yang plural.

\section{Daftar Pustaka}

Aminah, Siti \& Uli Parulian S. (2011). Memahami Pendapat Berbeda (Dissenting Opinion) Putusan Uji Materiil UU Penodaan Agama. Jakarta: ILRC.

As'ad, Muhammad. (2009). Ahmadiyah and the Freedom of Religion in Indonesia. Journal of Indonesian Islam. 3(2).

Bagir, Zainal Abidin. (2017). Kerukunan dan Penodaan Agama: Alternatif Penanganan Masalah. Yogyakarta: Center for Religious and Cross-cultural Studies (CRCS).

Burhani, Ahmad Najib. (2013). When Muslims are not Muslims: The Ahmadiyya Community and the Discourse on Heresy in Indonesia (A dissertation submitted to the Faculty of the University of California). ProQuest LLC.

Burhani, Ahmad Najib. (2014). "Hating the Ahmadiyya: The Place of "Heretics" in Contemporary Indonesian Muslim Society.” Contemporary Islam 8(2014):133-152.

Herdiansah, Ari Ganjar.(2016). "Public Policy and Religious Conflict in Indonesia: The Case of Ahmadiyah.” Jurnal Wacana Politik, 1: 1(2016):53-61.

Jurnal Socius: Journal of Sociology Research and Education Vol. 5, No.2, Th. 2018

ISSN: Online 2442-8663 - Print 2356-4180 
Human Rights Watch. (2013). Atas Nama Agama, Pelanggaran terhadap Minoritas Agama di Indonesia. tp.

Lambach, Daniel. (2004). "State in Society: Joel Migdal and the Limits of State Authority." Political Concepts Beyond the Nation State: Cosmopolitanism, Territoriality, Democracy, Danish Political Theory Network Conference, University of Copenhagen, Department of Political Science Copenhagen, 27-30 October 2004.

Migdal, Joel S. (2004). State in Society: Studying How States and Societies Transform and Constitute One Another. New York: Cambridge University Press.

Olle, John. (2009). "The Majelis Ulama Indonesia versus 'Heresy': Th Resurgence of Authoritarian Islam". State of Authority: The State ini Society in Indonesia. Ed. Klinken, Gerry van, and Joshua Barker. New York: Cornell Southeast Asia Program Publications.

Pamungkas, Cahyo (ed). (2017). Mereka yang Terusir: Studi tentang Jetahanan Sosial Pengungsi Ahmadiyah dan Syiah di Indonesia. Jakarta: Yayasan Pustaka Obor Indonesia.

Porter, D.J. (2002). Managing Politics and Islam in Indonesia. London \& New York: Routledge Curzon. 76-83.

Rahman, Fatima Zainab. (2014). State Restrictions on the Ahmadiyya Sect in Indonesia and Pakistan: Islam or Political Survival? Australian Journal of Political Science 49(3), 408-422.

Ramage, D.E. (1995). Politics in Indonesia: Democracy, Islam, and the Ideology of Tolerance. London and New York: Routledge. 30.

Saidi, Anas (ed). (2004). Menekuk Agama, Membangun Tahta: Kebijakan Agama Orde Baru. Depok: Desantara, 2004.

Sidik, Munasir. (2007). Dasar-dasar Hukum dan Legalitas Jemaat Ahmadiyah Indonesia. Tangerang: IKAHAI.

Tedlock, Barbara. (1991). From Participant Observation to The Observation of Participation: The Emergence of Narrative Ethnography, Journal of Anthropological Research 47(1), 69-94.

The Association of Religious Data (2010). http://www.thearda.com/internationalData/ countries/Country_109_2.asp. Diakses 20 Oktober 2018. 